\title{
11 The Landscape of Social Enterprise in the Slovak Republic
}

\author{
Zuzana Polačková
}

\section{Introduction}

Although the term "social enterprise" emerged in Slovakia only a few years ago, the concept of social entrepreneurship has a long tradition in the country, anchored in the 19th-century cooperative movement. The first legal definition of social enterprise was adopted in 2008 as part of the employment policy; it is one of the reasons why social enterprises in Slovakia are often narrowly associated with work integration. This narrow understanding is also one of the biggest challenges social enterprises are facing today. A gradually emerging ecosystem supporting the operation of social enterprises and the new legal framework on the social economy and social enterprises, adopted in $2018,{ }^{1}$ are currently contributing to an evolution of the perception of social enterprise towards its acknowledgement as a fully fledged component of the social economy and of the private sector.

\section{Historical Overview}

Unlike other countries from the region of Central Europe, Slovakia has a long tradition of civic engagement, mutual self-help and voluntarism whose roots go back to the 18th century. In the 19th century, alongside a variety of associations focused on a wide range of issues, the cooperative movement emerged and became an important economic actor. Later on, in the second half of the 19th century and by the turn of the 20th century, cooperatives played a central role in stimulating economic development and a self-governance model in the rural areas of Slovakia (BrozmanováGregorová et al. 2009). After World War I, under the First Czechoslovakian Republic (1918-1938), not only did production and agricultural cooperatives, operating primarily in the rural areas of Slovakia, become increasingly popular; this period was also marked by the emergence of credit unions and cultural and housing cooperatives (Stefancic et al. 2016).

The growing recognition of the cooperative movement was interrupted by political changes in 1948, when a brutal and massive nationalisation 
process was launched. The cooperative idea was co-opted for the purposes of the ideological advocacy of socialism, and cooperatives were incorporated into the state-controlled planned economic system. Although the principles and ethos of the cooperative movement were drastically misused, some cooperatives resisted and maintained their social role, primarily in regard to the employment of people with disabilities. During the 1980s, the Slovak Union of Producer Cooperatives, which was comprised of 17 cooperatives employing in total 7,000 disabled workers, was considered to be the main employer of people with disabilities in the country (DUSR 2018).

The Revolution of November 1989 introduced new socio-political conditions in the country, and a strong antagonism emerged against the cooperative concept, which was considered at the time as a synonym for socialism. On the other hand, the post-revolution period brought about an outburst of civic engagement, voluntarism and associations addressing a variety of issues that had been abandoned during the previous years.

In those days, discussions about social entrepreneurship had not occurred yet. The civic sector at that time received generous donations from international donors, which allowed for the construction of a lively ecosystem of non-governmental organisations (NGOs). However, after a decade of strong presence in the country, aiming towards democratisation and socio-economic transformation, international donors started to redirect their focus onto other regions, and the structure of resources available for the NGO sector changed significantly. A rapid decrease in accessible financial resources at the end of the 1990s triggered a discussion about alternative financial resources-which included, inter alia, resources generated by means of social entrepreneurship. At that time, social entrepreneurship was perceived as a means to support the multiplesource financing of NGOs, so the debate focused solely on the topic of entrepreneurship of NGOs as an instrument for co-financing their operations and core activities. The discussion was very much inspired by good practice from abroad, and stimulated by initiatives or international organisations, such as the Non-profit Enterprise and Self-sustainability Team (NESsT) or Ashoka, which were also active in Slovakia. But despite the emergence, in the late 1990s, of several initiatives among Slovak NGOs that can be considered as having pioneered social entrepreneurship in the country in today's sense of the word, social entrepreneurship was still an unknown concept at that time, and social enterprises (SEs) were carried out as separate business initiatives established by NGOs and conducted in a regular business setting-which, in practice, created complications in establishing organisations.

An important role in promoting social entrepreneurship in Slovakia was also played by the European EQUAL Community Initiative, which Slovakia implemented from 2004 onwards, after its accession to the European Union (EU). As part of the priority axis "Encouraging Inclusive 


\section{Polačková}

Entrepreneurship", a number of projects set up initiatives similar to current work-integration social enterprises (WISEs). For most of the Slovak organisations involved, this was their first ever contact with social entrepreneurship and with the creation of job opportunities for vulnerable groups. At the time, social entrepreneurship was still an unclear concept in the country; it was usually associated with the non-profit sector and often lacked an entrepreneurial element. Many of the supported projects lacked a viable business plan, and their activities were not financially sustainable without the project-based financing stemming from EQUAL or other external donor support. Once the financial support came to an end, the organisations could not usually sustain their SE initiatives.

This period was also crucial for the development of social enterprise in Slovakia for another reason. Indeed, several local municipalities ${ }^{2}$ entered one of the EQUAL-funded projects implemented in Slovakia and became an alternative to NGOs in supporting and implementing the idea of social entrepreneurship, and particularly WISEs (which still operated then without any regulatory framework).

\section{Legal Definition}

From the legal point of view, three major milestones can be distinguished in the history of Slovak social enterprises.

\subsection{The 2008 Definition of the "Work-Integration Social Enterprise"}

The first major milestone for Slovak social enterprises dates back to 2008. In response to the global economic crisis and to a sharp increase in unemployment rates, the Ministry of Labour, Social Affairs and Family amended Act No. 5/2004 on Employment Services, regarding inter alia the integration of disadvantaged employment applicants in WISEs. For the purposes of this law, a WISE is defined as

\section{(...) a legal or physical entity that:}

a) hires employees who, prior to their engagement, had been disadvantaged employment applicants, in an amount of at least $30 \%$ of the total number of employees;

b) provides support and assistance in connection with finding employment on the open labour market to employees who, prior to their engagement, had been disadvantaged employment applicants;

c) annually uses at least $30 \%$ of its financial resources, acquired in the form of the income from its commercial activities that remains after the payment of all expenditures for maintaining 
said activities in a given tax period, for creating new work positions or improving working conditions;

d) is registered with the Register of Work-Integration Social Enterprises.

2008 Amendment of Act No. 5/2004 on Employment Services, $\$ 50 \mathrm{~b}$

By means of this amendment, ${ }^{3}$ the government gave a legal entrenchment to WISEs and created a grant scheme intended for creating and sustaining jobs for vulnerable employees in these enterprises. The amendment did not differentiate between the concept of WISE and other types of social entrepreneurship; the downside of this form of inclusion of the concept of social entrepreneurship in Slovak law was a narrow definition of the concept of social enterprise, limiting it to work-integration initiatives. This gave rise to a limited perception of social entrepreneurship and an inadequate association of the concept of social enterprise with the purpose of creating job opportunities for disadvantaged groups, primarily people from marginalised Roma communities. Social enterprises in Slovakia still struggle nowadays with the heritage of this legal circumscription.

On the basis of the aforementioned 2008 amendment, a Register of WISEs was founded; it was administered by the Central Office of Labour, Social Affairs and Family. Any entity that wished to receive job subsidies administered under the active labour-market policy measures intended to create/sustain jobs for vulnerable employees was required to sign up in the Register and fulfil the conditions determined by the legislation on employment services, which defined social entrepreneurship.

Provisions related to wage subsidies for SE employees were cancelled in 2011. The support scheme was phased out mainly as a result of a scandal related to the misuse of some funds, which were allocated to eight entities that had falsely declared themselves as social enterprises. This created a situation in which a legal definition of social enterprise existed, but social enterprises did not have access to any support or any other type of recognition.

In such context, where being officially registered as a social enterprise provided no benefits whatsoever, the organisations quite naturally stopped paying attention to the fulfilment of their obligations and lost their registered status. As of the January 1, 2018, only ten social enterprises were still listed in the Register, ${ }^{4}$ while 89 entities had been removed from it as they had failed to fulfil their obligation to deliver an annual report. Thus, despite the existence of the 2008 legal framework, social enterprises in the period of 2010-2018 worked rather "organically", without any registration or systematic support targeted exclusively at them.

What is more, during the 2010s, the term "social enterprise" had a negative connotation in Slovakia, caused by the misuse of European funds in 


\section{Polačková}

the period of 2008-2010, as mentioned earlier. The terms "social entrepreneurship" or "social enterprise" were categorically rejected by policymakers for a number of years. To mitigate this problem, during that period, social entrepreneurship was relabelled with alternative terms, such as "interim labour market", "inclusive labour market" and so on.

\subsection{The 2015 Definition of the "Social-Economy Subject"}

In 2015, Act No. 5/2004 on Employment Services was amended again, and the term "social-economy subject" was introduced and defined:

1. [A social-economy subject is a] legal or physical entity that

a. sets the achievement of measurable positive social effects as its primary social objective within its statutes, other rules or founding documents, and

i. provides products or services to vulnerable, marginalised, disadvantaged or excluded persons, or

ii. employs a method of production or service provision that reflects its primary social objective;

b. allots at least $50 \%$ of its annual financial resources acquired in the form of the income from its commercial activities that remains after the payment of all expenditures for maintaining said activities in a given tax period for the achievement of its primary social objective;

c. is responsibly and transparently administered, especially in terms of involving employees, customers and interested parties whom its activities concern.

2. A legal or physical entity that sets the achievement of measurable positive social effects as its primary social objective within its statutes, other rules or founding documents, fulfils the conditions of sections $1 b)$ and 1c) and provides financial support to a social-economy subject according to section 1 is also considered as a social-economy subject.

2015 Amendment of Act No. 5/2004 on Employment Services, $\$ 50 \mathrm{a}$

This amendment broadened to some extent the concept and perception of social entrepreneurship, since it dropped the strict connection with labour integration. However, it did not produce any change in the existing support structures, and the amendment remained almost unnoticed. Indeed, despite this new amendment, no financial or non-financial support scheme was created by the state specifically for social enterprises. 


\subsection{The Adoption of Act No. 112/2018 on the Social Economy and Social Enterprises}

The recognition of social entrepreneurship among the general public was gradually growing, though. An important role in the rehabilitation of the social-entrepreneurship ethos was played by municipal social enterprises, which in general were considered as a promising example of good practice, both by politicians and by the general public. One of the results of such a good reputation was an entrenchment of social entrepreneurship in the government's National Employment Strategy and National Roma Integration Strategy up to 2020.

In 2016, this increased attention resulted in a governmental initiative aiming at the adoption of a comprehensive legislative framework for social entrepreneurship. The initiative was driven by the Ministry of Labour, Social Affairs and Family. After approximately two years of consultations involving a wide range of stakeholders (including social entrepreneurs, academia, municipality representatives and policymakers), in May 2018, Act No. 112/2018 on the Social Economy and Social Enterprises ${ }^{5}$ (hereinafter referred to as Act No. 112/2018) came into force. The new legislation brought about a change in terms of defining social entrepreneurship and created a supporting ecosystem, offering a spectrum of financial as well as non-financial assistance designed exclusively for social enterprises, funded by public resources or supported by the institutional framework of the SE sector.

According to Act No. 112/2018, a social enterprise is defined by following criteria:

a) it performs an economic activity in a systematic and independent way, in its own name and under its own responsibility;

b) its main objective is to achieve a measurable positive social impact;

c) it achieves a positive social impact through the production [or distribution] of goods or the provision of services (...);

d) it

I) creates a profit from its activities and uses more than $50 \%$ of the profits after taxation for achieving its main objective as referred to in point $b$ );

II) distributes part of the profits under the Commercial Code, and divides it according to procedures and rules that do not disrupt the main objective as defined in point b);

e) it involves stakeholders in the management of its economic activities. Act No. 112/2018 on the Social Economy and Social Entrepreneurship, $\mathbb{5}$

At the time of its adoption, the bill was criticised for its complexity and overemphasis on the implementation of control mechanisms aiming to 


\section{Polačková}

limit the possibilities of misuse of the SE legal form. Many social entrepreneurs considered the degree of emphasis on control mechanisms as a sign of distrust for their activity. However, the bill submitter (the Ministry of Labour, Social Affairs and Family) argued that a strong emphasis on control was rational and would contribute to a rehabilitation of social entrepreneurship in the eyes of the general public, who often regarded "social entrepreneurship" as a profane term associated with various media-based scandals about the massive misuse of public resources in the past. Despite the initial criticism, one may indeed argue that, one year after its adoption, the act had become widely accepted and valued.

\section{Size of the SE Sector}

Unfortunately, relevant statistical research in the area of the SE sector that would assess its scale and capacities does not exist in Slovakia yet. For this reason, it is difficult to produce relevant arguments based on quantitative data.

Act No. 112/2018 on the Social Economy and Social Enterprises, adopted in 2018, embeds social enterprises in the context of the social economy, which it defines as "the sum of production, distribution or consumer activities carried out by means of economic activity or noneconomic activity independently from state authorities, and whose main objective is to achieve a positive social impact". The social economy is thus defined as a set of activities that may be carried out by any entity from the business or non-governmental sector. It has to be underlined that a particular entity performing activities in the social economy is not necessarily a registered social enterprise but it is a so-called "socialeconomy subject".

Act No. 112/2018 considers as "social-economy subjects" the associations, foundations, non-investment funds and non-profit organisations providing public-interest services, religious associations, trade companies, cooperatives or individual entrepreneurs who (1) are not mostly or fully financed and managed by the state; (2) perform activities pertaining to an area of the social economy (i.e. their main objective is to achieve a positive social impact); (3) are not-for-profit, or use their profit to achieve a positive social impact. Social-economy subjects are established and managed under the specific legislation related to their legal form (e.g. civic associations are managed under the Associations Act). Act No. $112 / 2018$ tried to preserve, to the largest possible extent, the pluralism of the social-entrepreneurship sector in terms of legal forms.

Thirty months after the adoption of Act No. 112/2018, 230 entities had successfully applied for the status of registered social enterprise according to the Act and were listed in the Register. ${ }^{6}$ Among the approximately 54,000 civic associations and 3,400 non-profit organisations providing public-interest services, as well as among the 1,100 foundations or 
760 non-investment funds existing in Slovakia, many entities could also present all the characteristics of social enterprise such as they are defined by law, but for a variety of reasons, these entities never applied (and may never do so) for registration according to Act No. 112/2018. The Slovak SE sector thus largely extends beyond the boundaries of the existing Register of Social Enterprises.

The adoption of Act No. 112/2018 also brought about a significant change in that, it expanded the definition of entrepreneurship in the Commercial $\operatorname{Code}^{7}$ (Act No. 513/1991) to businesses aiming to achieve "measurable positive social impacts". Thus, a business entity recognised by the Commercial Code may now undertake economic activity to achieve a positive social impact without fulfilling the traditional purpose of business entities, which is to make profit. This change has opened up opportunities for entities that are traditionally regarded as businesses and primarily established for a profit purpose to join the group of socialeconomy subjects (Mészáros 2019). This evolution, though undoubtedly positive, makes the assessment of the size of the SE sector even more difficult.

All, but two, of the 230 currently registered social enterprises are work-integration-based organisations. However, the family of WISEs is surely wider, as a significant share of the approximately 1,200 sheltered workshops employing people with disabilities may be considered as social enterprises, even though they are not registered as such. Not all sheltered workshops, whose main characteristic is the employment of people with disabilities, can be considered as social enterprises, though; there is a large number of sheltered workshops that behave as traditional, profit-oriented enterprises, with no interest in allocating their possible profit to the pursuit of a social goal or in establishing a model of participatory governance.

Although the Register of Social Enterprises offers precise data about the number of social enterprises in Slovakia, considering such data as relevant information about the size of the social-entrepreneurship sector would be a mistake. Indeed, as already underlined, the Register of Social Enterprises only refers to a narrow category of social enterprises, namely those that are registered according to Act No. 112/2018. A significant number of social enterprises, operating under a wide variety of legal forms, are left out of the analysis, and no relevant data about their number or scale exist.

\section{The Specific Case of Municipal Social Enterprises}

A specific segment of the SE sector in Slovakia, which deserves special attention, is that of "municipal social enterprises". The only difference between municipal social enterprises and other social enterprises is the fact that municipal social enterprises are initiated by the local government 


\section{Polačková}

and their operation is monitored by the municipal council. These entities can be registered under various legal forms (they are usually limited companies), but they all share one characteristic - namely the fact that their founders and owners (or majority owners) are municipalities or regional governments.

From a social-economy and social-entrepreneurship theory perspective, it can be discussed whether municipal social enterprises, which are anchored in public administration, can be considered as "true" social enterprises or whether they are rather an expression of social innovation in public administration.

Critics argue that municipal social enterprises may have an advantage over other social enterprises in the area of public procurement, and that such advantage may distort economic competition. ${ }^{8}$ Regardless of the outcome of the debate about this specific point, it should be noted that municipal social enterprises cannot be considered as a universal solution; they are rather a "good model" for areas in which institutions other than local governments often do not exist. In such areas, where no business entities or NGOs operate, local government is often the only institution able to offer the human, social or financial resources necessary to implement any development initiative. Indeed, Slovakia has a high level of territorial administrative decentralisation, with 2,927 local authorities (for a population of approximately 5.5 million), and the local government often substitutes the sectors that are absent in the area.

The development of municipal social enterprises in Slovakia started in 2005 in the context of the EQUAL initiative, which supported SE projects. Initially, the projects' administrators planned to cooperate with NGOs, which traditionally deal with SE activities. This, however, proved difficult to achieve in the Slovak context, where the non-profit sector is primarily characterised by significant financial instability. Given the absence of strong NGOs in the SE field, the administrators of one of the projects supported under EQUAL decided to shift their attention towards the local government, implementing a joint action to support job creation for those furthest away from the labour market (mainly people from the Roma communities).

The current number of existing municipal social enterprises is not clear, as most of them are not registered under Act No. 112/2018 and are thus not included in the Register of Social Enterprises. This number cannot be deduced either from an analysis tracking the "social" attribute, as some of these enterprises deliberately avoid including the word "social" in their name. Indeed, as the public perception is that municipal social entrepreneurship is mainly associated with employment of people from Roma communities, some municipal enterprises that display all the characteristics of a social enterprise worry that their reputation may suffer from prejudices in society against these communities if they present themselves as social enterprises-hence their choice not to include the 
term "social" in their names. The number of municipal social enterprises cannot be identified based on their ownership structure either, as not every entity fully owned by a municipality can be considered as a social enterprise.

What is clear is that the interest in establishing municipal social enterprises is high. Based on research carried out in 2017 (Škobla et al. 2018), from a total of 528 local governments that participated in the research, ${ }^{9}$ $23 \%$ declared a high interest in establishing a municipal enterprise (122 municipalities), $22 \%$ declared that they would categorically refuse to do so and the rest were open to considering the possibility of establishing such an enterprise. Based on the same research, $6 \%$ of the municipalities (32 municipalities) declared that they ran a municipal social enterprise and $11 \%$ (58 municipalities) indicated that they had a past experience in managing a municipal social enterprise. Experts estimate the number of active and fully fledged municipal social enterprises with stable long-term operation across Slovakia to be around 25 to 30 .

Despite their relatively small number, municipal social enterprises play a crucial role in the discussion about the SE sector in Slovakia. Examples of good practice are widely communicated in the media and offer a strong argument for the support of social entrepreneurship en bloc. Their recognition among the general public is just as great as it is among politicians.

\section{Ecosystem Supporting Social Enterprises}

The discussion that preceded the introduction of Act No. 112/2018, and the adoption of this specific piece of legislation significantly expanded the debate on the nature of social entrepreneurship. The whole process that led to the adoption of this Act was rather participatory and involved a wide spectrum of stakeholders, and it attracted the interest of new actors in the arena of social entrepreneurship in Slovakia-in particular, financial institutions and a variety of other organisations that considered becoming social enterprises or incorporating social enterprises into their core business operation. Social entrepreneurship has also gradually started to appear in the portfolio of new governmental departments, ${ }^{10}$ which have started to experiment with social enterprises and accommodate them into the context of a variety of sectoral policies.

Nevertheless, despite these recent trends pointing to increasing support for social enterprise and the emergence of a variety of initiatives, the whole ecosystem supporting social entrepreneurship is still in its nascent stage. The key component of the existing ecosystem is Act No. 112/2018, and a crucial role is played by the Ministry of Labour, Social Affairs and Family of the Slovak Republic.

The implementation of Act No. 112/2018 is managed by the Department for Social Economy, which is part of the Ministry of Labour, Social 


\section{Polačková}

Affairs and Family. This department was established in accordance with the provisions of Act No. 112/2018 and consists of five full-time employees. ${ }^{11}$ The department's main role is to grant and repeal the status of registered social enterprise, to maintain the Register of Social Enterprises and to provide free consultations on the application process for obtaining the status of registered social enterprise.

With the objective of facilitating information about Act No. 112/2018 and positively promoting the operation of the SE sector, the Ministry of Labour, Social Affairs and Family established the Institute of Social Economy. This institute is not a legal entity; it is rather a large-scale project, financed by the European Social Fund, and it is gradually setting up and running a network of eight regional branches. These regional branches' main task is to provide free-of-charge information on social entrepreneurship and on Act No. 112/2018, as well as to assist with establishing new and supporting emerging social enterprises in their respective regions.

As of today, Act No. 112/2018 also offers a spectrum of financial and non-financial support; however, most of this support is accessible exclusively for registered social enterprises.

Within the category of financial support, the Act distinguishes two types of support: (1) investment aid and (2) compensatory aid.

Investment aid is based on a system combining a loan and a grant: the social enterprise may apply for a non-repayable grant, but at least $20 \%$ of the total budget of the investment plan must come from a loan. The quality of the investment plan is assessed by the financial institution to which the social enterprise applies for the loan. Once the financial institution agrees to provide the loan (repayable component of the investment), obtaining the grant (non-repayable component) is normally a mere formality.

In the case of compensatory aid, the focus is primarily (but not exclusively) on wage subsidies for disadvantaged employees in WISEs. The aid is distributed through the local labour offices, and any WISE that is registered and meets the conditions is entitled to it.

The financial assistance provided by the Ministry of Labour, Social Affairs and Family in accordance to Act No. 112/2018 is currently the key source of existing financial support for social enterprises. Activities of other departments in the field of SE support are unsubstantial.

Within the category of non-financial aid, support is provided primarily via the promotion of socially responsible public procurement and the introduction of service vouchers. Among other forms of non-financial aid offered by Act No. 112/2018, we may specifically mention the possibility to reduce the value added tax rate to $10 \%$ for goods and services provided by a registered social enterprise that uses $100 \%$ of its profit after taxation to achieve its primary objective. 
The expectations of policymakers are to move towards a wider implementation of socially responsible public procurement, which is considered to be an effective tool to support social enterprise. Sheltered workshops or "entities employing disadvantaged people" already enjoyed opportunities to conclude direct contracts with public authorities by virtue of the transposed Directive 2014/24/EU on Public Procurement, even before the adoption of Act No. 112/2018, but this Act has significantly extended the legal possibilities for the application of socially responsible publicprocurement procedures. A quota system, effective from January 1, 2020, provides that each contracting authority that issues more than ten calls for tenders annually has to apply social criteria for at least $6 \%$ of all its issued tenders. ${ }^{12}$

\section{SE Developmental Challenges}

The main stereotype that affects the perception of social enterprises in Slovakia is their unavoidable connection with the work integration of the hard-to-place unemployed, and particularly of people from marginalised Roma communities or people with disabilities. Because of such limited perception, a number of organisations that display all the characteristics of a social enterprise but do not employ people who are distant from the labour market, do not consider themselves to be social enterprises. It can be argued that this process of coupling social entrepreneurship with employment issues and work integration is a legacy of the first legal framework on social entrepreneurship, enacted in 2008. This limited perception of social entrepreneurship is also nourished by the fact that Act No. 112/2018 was initiated and drafted by the Ministry of Labour, Social Affairs and Family. This ministry is also the main technical secretariat for all matters related to Act No. 112/2018, and communication about this Act primarily takes place via the representatives of this ministry.

The strong orientation towards creating job opportunities for the hardto-place unemployed is also one of the reasons why social enterprises are often conflated with local initiatives that aim to create job opportunities in general. It is usual for a municipality or an NGO to create a number of job positions, fully subsidised through public employment services, and to call such an initiative a (municipal) social enterprise. However, these initiatives, in most cases, do not exhibit one of the primary characteristics of social entrepreneurship-namely the fact of supplying goods or services on the market or, in other words, of engaging in commercial activity; the jobs created within such initiatives are fully dependent on external financial subsidies.

Other stereotypes often link social enterprises with endeavours focused on the social integration of people from marginalised Roma communities. Given the high level of social exclusion suffered by marginalised 


\section{Polačková}

Roma communities in Slovakia, the involvement of social enterprises in this area is natural but not a matter of course. The attitude of local actors that claim not to need a social enterprise "because there are no Roma in their locality" is, of course, entirely unsound but not unusual. It can be argued that the perception of social enterprises through the lens of the social inclusion of people from marginalised Roma communities is a legacy of actual facts, to the extent that the most successful and visible social enterprises, be they established by municipalities or non-governmental organisations, are largely involved in issues concerning the social inclusion of Roma people.

One peculiar feature of social entrepreneurship in Slovakia is the fact that Slovak social enterprises are usually founded in a "top-down" way, on the initiative of an organisation, spurred by the presence of a certain social problem. Social enterprises founded on the initiative of those who are personally touched by a social problem-that is to say, through a "bottom-up" process-are rare. Research (Bútorová 2017) argues that individuals willing to participate in designing and implementing solutions to societal challenges are usually those with a higher education and higher income, while people facing the worst economic conditions-who are also often, regardless of their ethnic background, those facing a variety of challenges-are often more passive and appear more likely to be waiting for help from authorities. Individuals' socioeconomic stability and social capital are seen as one of the key conditions defining their readiness to participate in public life. For this reason, having local governments initiate social enterprises is not unusual in the Slovak environment, and it is the reason why municipal social enterprises-and specifically those focused on the improvement of the life conditions in the marginalised Roma communities-are highly accepted by the public.

Among the other challenges that Slovak social enterprises face, we could also highlight the lack of entrepreneurial skills among potential social entrepreneurs; this is particularly true in social enterprises initiated by NGOs. The NGO sector in Slovakia offers a number of great examples with high entrepreneurial potential, which could be easily converted into social enterprises. The main obstacle is usually a lack of entrepreneurial skills and a culture of strong dependency on external donations and financing, which is a characteristic of the non-profit sector in Slovakia. Potential social enterprises often invest significant energy into application processes for funding from external donors, instead of being focused on the cultivation of their own entrepreneurial potential. This focus on external grants rather than on income generation often leads to the disqualification of social enterprises in the eyes of traditional business-sector entities, which only rarely respect social enterprises as full and equal business partners. 


\section{Conclusion}

The SE sector in Slovakia has recently experienced a dynamic development. Among other factors, such development is surely nourished by the international context, in which social enterprises are seen as an innovative and effective answer to a variety of societal challenges. However, the growing scope and increasing quality of the discussion about the nature and role of social enterprises in Slovakia are certainly also influenced by the adoption, in May 2008, of a comprehensive legislative framework on the social economy and social enterprises. Although it is undeniable that the existence of even the best-quality law is not a guarantee of a fully functional and supportive ecosystem, recent experience shows that the adoption of adequate legislation may highly stimulate the interest of a variety of actors, who may in turn contribute to the overall success of the sector. Despite the challenges identified earlier, recent trends in SE development thus give us cause for optimism about the future of the SE sector in Slovakia.

\section{Disclaimer}

The author of this chapter is a member of the taskforce that formulated and drafted Act No. 112/2018 Coll. on the Social Economy and Social Enterprises.

\section{Notes}

1. Act No. 112/2018. Explanatory report is accessible at www.epi.sk/dovo dova-sprava/dovodova-sprava-k-zakonu-c-112-2018-z-z.htm.

2. For more information about the concept of municipal social enterprises, see Section 4.

3. Act No. 5/2004 Coll. on Employment Services, accessible on www.slov-lex. sk/pravne-predpisy/SK/ZZ/2004/5/20180401.html.

4. Social enterprises registered in accordance with Act No. 5/2004 on employment services, that is, under the 2008 legal definition of social entrepreneurship. The Register was cancelled by the adoption of a new law in May 2018.

5. Act No. 112/2018 Coll. on Social Economy and Social Enterprises, accessible on www.slov-lex.sk/pravne-predpisy/SK/ZZ/2018/112/.

6. The Social Enterprises Register, administered by Central Office of Labour, Social Affairs and Family, is accessible on www.employment.gov.sk/sk/pracazamestnanost/socialna-ekonomika/.

7. Act No. 513/1991 Coll. Business Code, accessible on www.slov-lex.sk/pravnepredpisy/SK/ZZ/1991/513/20160701.

8. The business activities of many municipal social enterprises are related to the administration and maintenance of municipal property.

9. The research was carried out, using a questionnaire, on a sample of municipalities from the three regions (namely Košice, Prešov and Banská Bystrica) where the socio-economic situation is considered to be the most complicated in the country. Out of the 1,621 local governments that were invited to take 


\section{Polačková}

part in the survey, 528 municipalities answered the questionnaire (i.e. the response rate was $33 \%$ ).

10. For example, the Ministry of Economy of the Slovak Republic or the Ministry of Culture of the Slovak Republic.

11. As of September 2020.

12. Act No. 343/2015 Coll. on Public Procurement, accessible on www.slov-lex. sk/pravne-predpisy/SK/ZZ/2015/343/20160418.html.

\section{References}

Brozmanová-Gregorová, A., Aldolfová, I., Hirt, B., Kunická, J., Pirošík, V., Štulajterová, A. \& Vrbický, L. (2009) Tretí sector a mimovládne organizácie, Banská Bystrica: Univerzita Mateja Bella.

Bútorová, Z. (2017) “Občianska participácia a minovládne neziskové organizácie očami verejnosti”, in Mesežnikov, G. \& Strečanský, B. (eds) Občianska spoločnost’ na Slovensku, Krízy, križovatky, výzvy, Bratislava: Inštitút pre verejné otázky.

DUSR (2018) 25 rokov družstevnej únie, Bratislava: Družstevná únia Slovenskej Republiky.

Mészáros, P. (2019) “Spoločenska prospešnost' v novom šate alevo napĺn̆anie pozhitívneho sociálneho vplyvu v kontexte zákona o sociálnej ekonomike a sociálnych podnikoch”, in Polačková, Z. (ed) Ročenka sociálneho podnikania, Bratislava: PU SAV.

Škobla, D., Kováčová, L. \& Ondoš, S. (2018) Sociálne podniky pracovnej integrácie na Slovensku: Súčasné skúsenosti a budúce perspektívy, Bratislava: SGI.

Stefancic, M., Korimová, G. \& Polačková, Z. (2016) A Map of Social Enterprises and Their Eco-Systems in Europe, Country Report Slovakia 2016 for EURICSE and European Commission, Trento and Brussels: European Research Institute on Cooperative and Social Enterprises and European Commission. 